\title{
The efficacy of fortified human milk compared to human milk alone for the growth of low birth weight infants
}

\author{
Dewi Kumara Wati Ketut, MD; Soetjiningsih, MD; Suandi IKG, MD; Hamid HA, MD
}

\begin{abstract}
Objective To evaluate the growth of low birth weight infants fed by fortified human milk (FHM) compared to human milk (HM) alone. Methods Sixty premature infants enrolled in this study and randomly assigned to have FHM and HM delivered by infusofeedpump, in parallel, non-blinded controlled trial. All patients were followed until day 30 or until discharge, whichever came first. The weight gain was recorded daily, while length and head circumference increment were recorded weekly.

Results The FHM group gained more weight than the HM group $(335.0 \pm 55.5 \mathrm{~g}$ vs. $290.6 \pm 108.4 \mathrm{~g}, \mathrm{p}=0.000,95 \% \mathrm{Cl}-170.2 ;-81.2)$ larger length increment $(1.9 \pm 1.1 \mathrm{~cm}$ vs. $1.2 \pm 0.4 \mathrm{~cm}, \mathrm{p}=0.000,95 \% \mathrm{Cl}$ $-1.37 ;-0.55)$, and larger head increment $(1.87+1.1 \mathrm{~cm}$ vs. $0.91 \pm 0.43 \mathrm{~cm}, 95 \% \mathrm{Cl}-1.37 ;-0.55)$. A similar result was found when the group was divided into subgroup of $1000-1499 \mathrm{~g}$ and 1500$1999 \mathrm{~g}$ birth weight. The larger calorie intake in the FHM group was the reason for better growth. No adverse effect related to the intervention was found.

Conclusion The study shows the benefit of FHM in growth of low birth weight infants, which is consistent when the group is divided into $1000-1499 \mathrm{~g}$ birth weight and 1500-1999 g birth weight sub groups. Better growth is achieved through higher calorie intake in the FHM group. No adverse effect is found as a consequence of intervention [Paediatr Indones 2003;43:177-185].
\end{abstract}

Keywords: low birth weight infants, human milk, human milk fortifier, growth

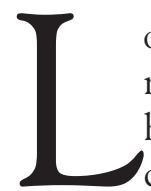

ow birth weight infants remain one of the major problems in neonatology due to their high morbidity and mortality. As a referral center, Sanglah hospital noted the incidence of low birth weight (LBW) infants as high as 20\% which was higher than the national incidence rate $(13 \%)^{1-3}$ and with a high mortality rate, which reached
$58.1 \% .4-6$ Nowadays the survival rate of LBW infants has improved, but the quality of their life must be maintained, particularly by considering their nutritional needs. Since LBW infants remain vulnerable to infection, adequate feeding will help them to overcome this problem, as well as to meet the need to catch up growth. ${ }^{7}$ Breast milk has limitations due to the reduction of its protein and energy contents after 2 weeks post natal age and low contents of calcium and phosphorus ${ }^{10-13}$ despite its superiority due to nutrient quality, immunity, ability to stimulate maturation of gastrointestinal tract, decreased incidence of sepsis, necrotizing enterocolitis, and mother-infant relationship. ${ }^{14-20}$ However, particular attention has been focused on human milk fortifier which gives more energy and nutrients to human milk, as shown in study by Greene et al ${ }^{8}$ and Schanler. ${ }^{9}$ To maintain intrauterine growth, Schanler 9,21,22 suggested to fortify the human milk for at least 2 months post natal. At Sanglah Hospital of Denpasar, policy on using human milk fortifier had not been started yet. Supplementation of human milk fortifier

From the Department of Child Health, Medical School, University of Udayana Sanglah Hospital, Denpasar.

Reprint requests to: Ketut Dewi Kumara Wati, MD, Department of Child Health, Medical School Udayana University, Sanglah Hospital, Bali, Indonesia. Tel/Fax. 62-361-244038. 
would encourage the use of human milk and cope with Sanglah Hospital as a baby friendly hospital.

The primary aim of the study was to compare the growth of LBW infants fed by fortified human milk (FHM) with that of fed by human milk alone (HM) by comparing their weight gain, length, and head circumference increment at the end of the study. The secondary aims were to asses the growth of 1000-1499 g and 1500-1999 g subgroup, total calories and volume intake, days of full feeding attainment, and adverse reactions of the control and intervention groups.

\section{Methods}

The study was a prospective, randomized, parallel, non blinded controlled trial to compare the growth of LBW fed by fortified human milk with that of fed by human milk. Based on standard calculation formula, thirty subjects were needed in each group to detect the differences in body weight, length and head circumference after thirty days of observation, with $\alpha$ $<0.05$ and $\beta=80 \%$. Random assignment was done using a random table, while the type of milk given was determined by throwing a coin and the number was placed in a sealed envelope. ${ }^{21}$ If there was an eligible subject, the envelope would be randomly taken, from which this subject will have his/her own number and milk group. Hence, milk was given based on the number within the envelope.

Study setting was in the Neonatology Subdivision, Department of Child Health, Sanglah Hospital, Denpasar, conducted between November 2000 and October 2001. The population was all LBW born in Sanglah Hospital throughout the time of the study.

Sample was LBW with inclusion criteria as follow: birth weight between 1000-1999 g, gestational age less than 34 weeks based on last menstrual date, appropriate for gestational age (AGA), singleton or twin births, stable to start enteral nutrition, and fed only by human milk in the first 2 weeks of life.

While the exclusion criteria were any confounding factors, such as asphyxiated on birth, major congenital anomalies, severely sick, such as pneumonia, sepsis, meningitis, bronchopulmonary dysplasia, hydrocephalus, bleeding, anemia, hyperbilirubinemia, hypothermia, any contraindication for enteral nutrition, such as gastrointestinal tract disturbances, res- piratory distress, abdominal distention, cyanosis, seizures, and apnea.

A low birth weight infant was defined as an infant born with birth weight less than $2500 \mathrm{~g}$. For analysis, the group was divided into birth weight between $1000-1499 \mathrm{~g}$ and $1500-1999 \mathrm{~g}$. Those with birth weight above $2000 \mathrm{~g}$ were not included due to a much shorter period to reach full feeding and so were the hospital stay, which mean a short period of observation. While those who were below $1000 \mathrm{~g}$ of birth weight were not included due to low survival rate.

Continuous enteral nutrition was delivered by a device called infusofeedpump (GoMedical Lab, Subiaco, Australia) that provided continuous feeding without gravity after attached to the nasogastric tube. Silicon elastomere balloon of the infuso feed pump provide the ability of the balloon to expand up to volume of 200 and $400 \mathrm{cc}$. When it was filled, the fluid within would give tension to the balloon and permit the fluid to drop continuously depending on the rate of the dropper through a one way valve. The rate of the dropper was set at $50 \mathrm{cc} / \mathrm{h}$ or 1 drop in 3 second. ${ }^{24}$ This rate was acceptable by LBW infants with respect to the gastric load. Balloon volume of $200 \mathrm{cc}$ and $400 \mathrm{cc}$ were used for the reason that many LBW feeding could be covered in a single filling.

LBW infants fed by human milk were LBW infants fed by their mother's milk or other LBW's mother if the mother's milk was insufficient. In case of human milk was unavailable, formula was given with a criterion of not exceeding $40 \%$ of total milk consumed.

LBW infants fed by fortified human milk was defined as LBW infants fed by fortified human milk either taken from their mother's milk or other LBW's mother's milk if their mother's milk was insufficient. In case of human milk was unavailable, formula was given with a criterion of not exceeding $40 \%$ of total milk consumed.

The weight of the infants was measured daily according to the standard procedure, started at study day 1 , until full feeding was attained, while length and head circumference were measured weekly according to the standard procedure, started at study day $1 \mathrm{un-}$ til full feeding was attained.

Adverse events of feeding practice were defined as each clinical sign that was documented during the clinical trial that resulted in death or was life threatening including pulmonary central autonomic, such 
as apnea, cyanosis; pulmonary parenchymatous, such as aspiration pneumonia; non pulmonary, such as diarrhea, spitting, vomiting, abdominal distension, residual volume of $>20 \%$ or sepsis. If subjects demonstrated such an adverse event, feeding would be withheld until the clinical condition was stable to start refeeding.

\section{Study protocol}

\section{Procedure}

Subjects were measured for weight, length, and head circumference within 30 minutes after birth. LBW infant who met the inclusion and exclusion criteria, started the study protocol. After informed consent was obtained, campaign of human milk advantages and methods of breast milk expression and storing were given. Mothers were encouraged to express their milk 30 minutes before the feeding schedule of their babies. In case of no breast milk expressed or breast milk was insufficient, human milk was taken from other LBW mothers' milk. If human milk was not available, formula would be fed in volume of not more than $40 \%$ of total milk consumed during the study. Calculation of the type and amount of milk was written on a list. Baseline data was taken from mother and baby's medical record. Feeding was started as soon as the baby condition was stable, using nasogastric tube and continuous drip provided by infusofeedpump. Feeding was started by priming method at $0.75 \mathrm{cc} / \mathrm{kg} /$ feeding, repeated every 2 hours, and increased $1 \mathrm{cc}$ every 12 hours, until attainment of full feeding $(150 \mathrm{kcal} / \mathrm{kg} /$ day). From that day on, feeding was given constantly every two hours. Before full feeding was attained, IVFD was given to fulfill the fluid daily requirement.

On day 1 to 14 , only human milk was given to both groups. On day 15, human milk alone was continued for control group until discharge, while experimental group received fortified human milk, by adding $4 \mathrm{~g}$ human milk fortifier (SMA/S26 Human Milk Fortifier, Wyeth Nutritional International) in $100 \mathrm{cc}$ human milk until discharge. Human milk and HMF were shaken thoroughly in horizontal direction. The mixture could be stored in a refrigerator for 24 hours before used. ${ }^{11,12,23}$

If any adverse effects were documented, feeding was withheld, followed by an evaluation to consider whether feeding could be continued after the management of the adverse effect that did not exceed 3 days or the subject must be excluded from the trial. The management of the adverse effect was done according to the ward's guideline. During the study, all standard guidelines like incubator, IVFD, or drugs such as vitamin $\mathrm{K}$ and antibiotics for infection, were given if there was an indication. Albumin level was checked on day 7 and it would be given if the level was below $3.5 \mathrm{~g} / \mathrm{dL}$. On 34 weeks post conceptional age, coordination between sucking and swallowing reflexes and respiration was tested and oral feeding would be started if it showed good coordination.

Growth evaluation was done after 30 days or until discharge, whichever comes first. The indications for discharge were clinically in good condition, able to have oral feeding, satisfactory weight gain, and mother able to take care of the infant at home. Recording of infant's weight was done daily, length and head circumference measurements were done weekly. Adverse effect was evaluated before, during and after every feeding.

\section{Blinding}

Blinding was not conducted, since physically, human milk and fortified human milk differ in color.

\section{Statistical analysis}

Statistical analysis was done to all subjects. Baseline characteristic data in both groups were reported descriptively. Independent $t$ test was used to analyze the significance of growth outcome differences between both groups; ANOVA and Post Hoc were used to analyze growth outcomes in 1000-1499 $\mathrm{g}$ and 1500-1999 g subgroup. Multiple regression was used to define the most influencing factor that affected the growth outcome. Analysis was done based on intention to treat, using SPSS 11.0 computer program for Windows, with significance level of $p<0.05$ and confidence interval of $95 \%$.

\section{Results}

\section{Subjects' characteristics}

During the study period from Nov 2000 to October 2001, of 204 neonates born in Sanglah hospital, 60 
were enrolled in the study. After randomization, 31 subjects were assigned to control (the HM group), whilst 29 subjects were assigned to the experimental group (the FHM group). Four subjects were withdrawn from the control group, (2 died due to sepsis, 2 were discharged before the study completed), while in experimental group, 2 subjects were withdrawn due to sepsis and discharged before the study completed. No significance differences were found between both groups. (Table 1)

Recruited and drop out scheme of study subjects is shown below (Figure 1).

\section{Primary outcome}

\section{Weight gain, length, and head increment}

Both group showed increased growth during the study. Weight gain in the FHM group was more than that of the HM group, which was statistically significant $(335 \pm 55.5$ vs. $290.6 \pm 108.4, p=0.00 ; 95 \% \mathrm{CI}$ 170.2;81.2). Length increment was also higher in the FHM group $(1.98+1.1$ vs. $1.2 \pm 0.4, p=0.000,95 \% \mathrm{CI}$ $-1.37 ;-0.55)$ and so was head circumference increment $(1.87 \pm 1.1$ vs. $0.91 \pm 0.43, p=0.000,95 \%$ CI $[-1.37$ $;-0.55]$. The primary outcome is shown in Table 2 .

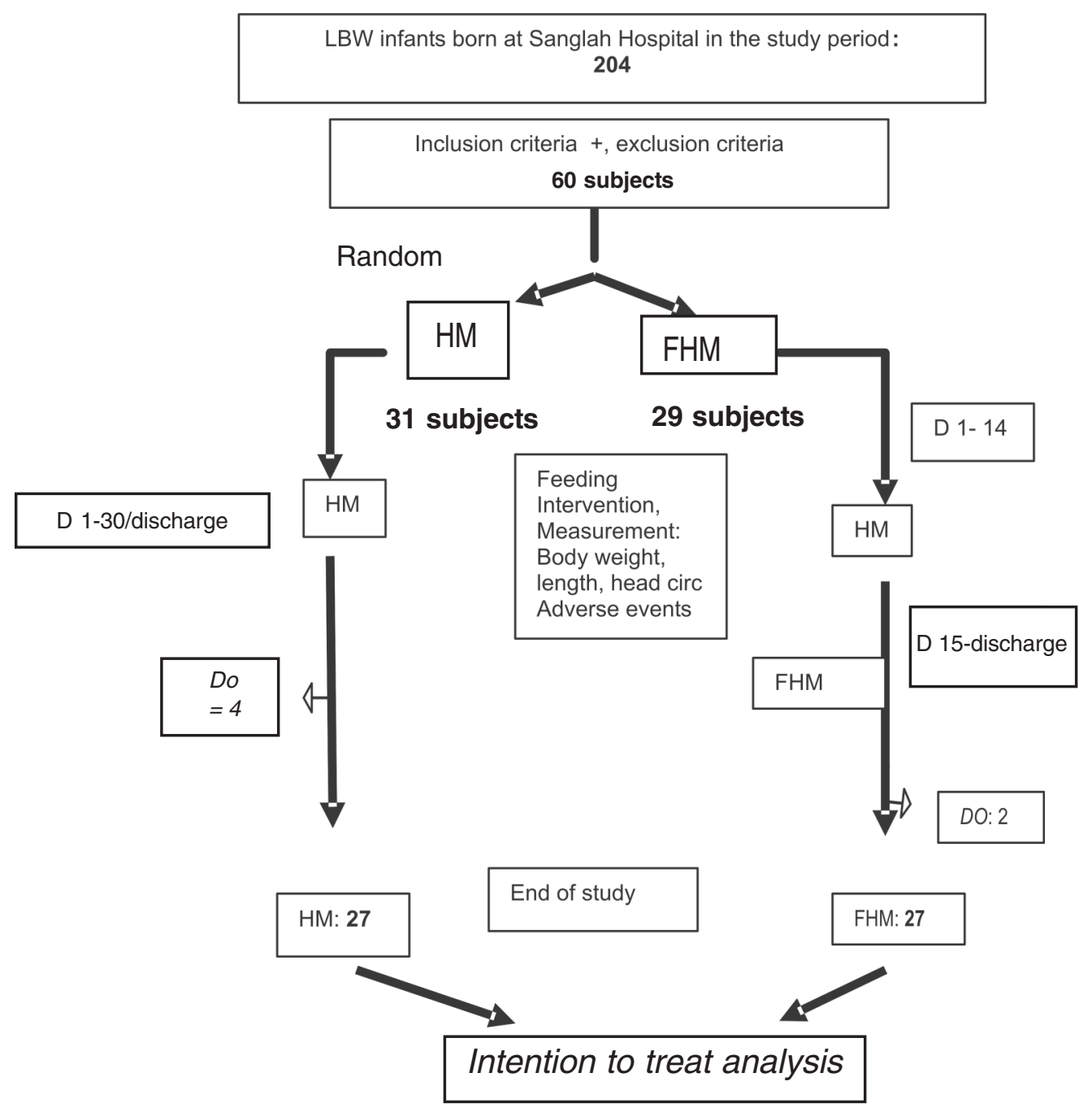

Figure 1. Recruitment and drop out of study subject 
Dewi Kumara Wati Ketut et al: The efficacy of fortified human milk for the growth of LBW infants

Table 1. Subject's Characteristics

\begin{tabular}{lll}
\hline & HM & FHM \\
\hline Subjects' number & 31 & 29 \\
Completed study & 27 & 27 \\
Drop out from study & 4 & 2 \\
\hline Gender & & \\
Male & 18 & 16 \\
Female & 13 & 13 \\
Gest age (weeks), mean \pm SD & $28.7 \pm 1.8$ & $29.8 \pm 1.9$ \\
Birth weight (g), mean \pm SD & $1347 \pm 186.7$ & $1495.9 \pm 175$ \\
Birth length (cm), mean \pm SD & $35.9 \pm 2.5$ & $37.7 \pm 2.6$ \\
Head circumference (cm) mean \pm SD & $25.7 \pm 2.5$ & $27.1 \pm 2.3$ \\
\hline Age on study day 1 & $1.6 \pm 0.8$ & $1.4 \pm 0.6$ \\
\hline Mother's age (yrs), mean \pm SD & $27.1 \pm 4.5$ & $27.6 \pm 3.7$ \\
Mother's weight (kg), mean \pm SD & $58.0 \pm 3.2$ & $58.4 \pm 2.4$ \\
\hline
\end{tabular}

Table 2. Primary outcomes of LBW infants fed by human milk vs. FHM based on INTENTION TO TREAT ANALYSIS

\begin{tabular}{lllll}
\hline & $\mathrm{HM}$ & $\mathrm{F} \mathrm{H} \mathrm{M}$ & $P$ & $95 \% \mathrm{Cl}$ \\
\hline Birth weight , g & $1347.7 \pm 186.8$ & $1495.8 \pm 175$ & 0.007 & $-241.8 ;-54.4$ \\
Weight at end of study, g & $1522.9 \pm 274$ & $1807 \pm 181.4$ & 0.000 & $\mathbf{- 4 0 5 . 7 ; - 1 6 3 . 6}$ \\
Weight gain, g & $\mathbf{2 9 0 . 6 \pm \mathbf { 1 0 8 . 4 }}$ & $\mathbf{3 3 5} \pm \mathbf{5 5 . 5}$ & $\mathbf{0 . 0 0 0}$ & $\mathbf{- 1 7 0 . 2 ; - 8 1 . 2}$ \\
Birth length, cm & $35.9 \pm 2.5$ & $37.7 \pm 2.6$ & 0.000 & $\mathbf{- 3 . 2 ; - 5 . 4}$ \\
Length at end of study, cm & $36.9 \pm 2.7$ & $39.6 \pm 3.3$ & 0.000 & $-4.3 ;-1.2$ \\
Length increment,cm & $\mathbf{1 . 2} \pm \mathbf{0 . 4}$ & $\mathbf{1 . 9} \pm \mathbf{1 . 1}$ & $\mathbf{0 . 0 0 0}$ & $\mathbf{- 1 . 4 ; - 0 . 6}$ \\
Head circ at birth, cm & $25.7 \pm 2.4$ & $27.1 \pm 2.3$ & 0.000 & $-2.6 ;-0.1$ \\
Head circ at end of study, cm & $26.6 \pm 2.6$ & $28.9 \pm 2.9$ & 0.000 & $-3.8 ;-0.8$ \\
Head increment, cm & $\mathbf{0 . 9 1} \pm \mathbf{0 . 4 3}$ & $\mathbf{1 . 9} \pm \mathbf{1 . 1}$ & $\mathbf{0 . 0 0 0}$ & $\mathbf{- 1 . 4 ; - 0 . 6}$ \\
\hline
\end{tabular}

Note: Data presented in mean \pm SD

\section{Secondary outcome}

\section{Subgroup analysis}

Subgroup analysis was performed to minimize bias provided by birth weight differences. The group was divided into babies born with body weight of 1000 . $1499 \mathrm{~g}$ and 1500-1999 g. Analysis was based on milk type received by both groups. This analysis showed that LBWs with birth weight of 1000-1499 gram in the FHM group gained more weight compared to those in the HM group, which was statistically significant $(315.38+55.47$ vs.186.19 +101.67 , $\mathrm{p}=0.00 ; 95 \%$ CI $-184.15 ;-3.46)$. In the $1500-1999$ g subgroup, those in the FHM group also showed more weight gain compared to those in the HM group, although this difference was not significant $(352.67 \pm 51.19$ vs. $280.0 \pm 77.46 ; p=0.18 ; 95 \% \mathrm{CI}$ $-22.25 ; 167.59)$. A similar result was found in length increment between both 1000-1499 g subgroups $(1.40 \pm 0.67$ vs. $0.96 \pm 0.28 ; p=0.25 ; 95 \% \mathrm{CI}$ $0.44 ; 0.250)$. In the $1500-1999 \mathrm{~g}$ subgroup, more length increment was attained in the FHM group, but this was not significant either $(2.48 \pm 1.08$ vs. $1.22 \pm 0.45 ; p=0.275 ; 95 \%$ CI $[0.39 ; 1.76])$. In the 1000-1499 g subgroup, those in the FHM group gained more head circumference increment compared to those in the HM group, $(1.23+0.72$ vs. $0.81 \pm 0.37 ; \mathrm{p}=0.275 ; 95 \% \mathrm{CI}-0.84 ; 0.81)$. A similar result was also found in the $1500-1999 \mathrm{~g}$ subgroup $(2.42 \pm 1.01$ vs. $1.25 \pm 0.43 ; \mathrm{p}=0.002$; 95\%CI $0.35 ; 1.98)$.

\section{Milk volume, total calories, full feeding and length of stay}

Table 3 shows that total volume consumed by the FHM group was less than that of the HM group, although this finding was not significant. On the other hand, total calories consumed by the FHM group were more than those of the HM group and this was statistically significant. Days of full feeding was achieved earlier by the FHM group (not 
Table.3. Secondary outcome In LBW Less than 34 WeEks of Gestational Age fed BY FHM vs. HM

\begin{tabular}{lllll}
\hline & HM & FHM & p & $\mathbf{9 5 \% C l}$ \\
\hline Total milk consumed (cc) & $5663 \pm 563$ & $5290 \pm 887$ & 0.07 & $-36.9 ; 782.3$ \\
Total calorie (cal) & $4110 \pm 361$ & $4535 \pm 779$ & 0.13 & $-761.0 ;-88.0$ \\
Full feeding (days) & $7.0 \pm 0.4$ & $6.3 \pm 0.6$ & 0.001 & $0.5 ; 0.9$ \\
Length of stay (days) & $28.8 \pm 3.0$ & $29 \pm 2.3$ & 0.51 & $-1.8 ;-1.2$ \\
\hline
\end{tabular}

Data presented in mean $\pm \mathrm{SD}$

Table 4. Relation among variables that influence weight gain, Length, and head CIRCUMFERENCE INCREMENT IN THE FHM AND HM GROUPS BY MULTIPLE REGRESSIONS ANALYSIS

\begin{tabular}{|c|c|c|c|c|c|c|}
\hline & \multicolumn{2}{|c|}{ Weight gain* } & \multicolumn{2}{|c|}{ Length increment ${ }^{\star *}$} & \multicolumn{2}{|c|}{ Head increment ${ }^{\star \star \star}$} \\
\hline & $\mathbf{t}$ & $\mathbf{p}$ & t & $\mathbf{p}$ & $\mathbf{t}$ & $\mathbf{p}$ \\
\hline Sex & -0.1 & 0.916 & -0.6 & 0.523 & -0.8 & 0.418 \\
\hline Gestational age & 1.5 & 0.149 & -1.2 & 0.237 & -0.1 & 0.908 \\
\hline Birth weight & -0.6 & 0.544 & -2.1 & 0.039 & -1.4 & 0.045 \\
\hline Birth length & -1.0 & 0.314 & 3.2 & 0.002 & 2.7 & 0.010 \\
\hline Head circumference at birth & 0.2 & 0.858 & 0.5 & 0.624 & 0.0 & 0.736 \\
\hline Age & -1.7 & 0.989 & -0.2 & 0.898 & -1.2 & 0.206 \\
\hline Milk & 5.3 & 0.000 & 0.2 & 0.000 & -0.3 & 0.003 \\
\hline ANOVA: $6.516 ; p=0.000$ & & & & & & \\
\hline ** F ANOVA: 7.737; $p=0.000$ & & & & & & \\
\hline *** F ANOVA: $7.290 ; p=0.000$ & & & & & & \\
\hline
\end{tabular}

significant), while length of stay was similar between both groups.

\section{Influence of other factors}

Multiple regression analysis was conducted to define whether other factors confounded the primary results as shown in Table 4.

This table showed that milk type has a great significance $(t=5.2999 ; p=0.000)$ as a factor that promotes weight gain, independent from the other factors. This phenomena was also seen in length increment in which milk type also influenced the increment $(t=4.171 ; p=0.000)$ although length at birth also influence the increment $(t=3.219 ; \mathrm{p}=0.02)$. For head circumference increment, milk type was the only factor that influence the increment $(t=-0.348$; $\mathrm{p}=0.003$ ). These results were consistent with previous analysis which means that FHM gave weight gain, length and head increment better than human milk alone.

\section{Adverse effects}

Although no serious adverse effects were reported as being intervention effects, some subjects were dropped out during the study. Sepsis events were noted in 4 babies after day 7 and were associated with premature rupture of the membrane ( 2 subjects) and 2 subjects did not complete the study.

\section{Discussion}

Human milk fortifier (HMF) added to human milk (HM) has been widely investigated which resulted in significant weight gain. $8,10,12,25-28$ In consistence with those researches, our study showed different growth outcomes between the Fortified Human Milk (FHM) group and the Human Milk (HM) group alone in which the FHM group significantly gained more weight, length and head circumference.

The reason for more gain was due to more calories provided by FHM compared to HM alone, as shown in secondary results. FHM contained $1 \mathrm{~g}$ more protein which provided more essential amino acid for growth. Whey protein contained in FHM, disperses more easily, thus, easier to be absorbed and used effectively by LBW infants. On the other hand, polymer glucose is also easier to be absorbed. ${ }^{29-30}$ This was consistent with the study of Schanler which gave FHM to LBW infants of 28-30 weeks of gestational age and 
showed weight gain at the same rate to intrauterine growth. ${ }^{12}$

Length increment in the FHM group was better than that of the HM group, which was consistent with the study of Schanler. ${ }^{9}$ This result was probably provided by mineral addition, particularly calcium and phosphorus, which improves calcium and phosphorus status as well as alkaline phosphatase activity, which in turn results in better bone mineralization and length increment. ${ }^{26}$

Head circumference increment is a manifestation of brain volume increase. This increment may be secondary provided by energy addition in the FHM group. As enough energy given, infants in the FHM group did not need to use free fatty acid as energy and resulted in free fatty acid accumulation in brain cells membrane which in turn led to the opportunity of brain cells to grow. ${ }^{15,27-28}$

Because the fastest growth of LBW is in the third trimester of intrauterine life, then we have to provide sufficient energy in this period to achieve the proper growth in extrauterine life. ${ }^{22,25,31}$ The proper energy must be added, especially after 2 weeks post natal to prevent malnutrition results from the reduction of energy in human milk. ${ }^{21}$ The weight gain of the 1000 $1499 \mathrm{~g}$ sub group was greater than that of the 1500 . 1999 g sub group. It was not clear, whether this achievement was a result of a greater growth velocity of the 1000-1499 g compared to that of the 1500-1999 g. Based on the fact that the weight gain was achieved during the study, then the longer length of stay of the former subgroup would provide more advanced health care.

We did not find any adverse effects or intolerances due to HM nor FHM used. This fact may result from the benefit of giving HM, the most appropriate nutrient for human infant, combined by the appropriate method of feeding. Priming procedure used in this study allowed the practice to start feeding earlier, which prevented villous atrophy and dysfunction by introducing nutrition to the gastrointestinal tract. This aimed to give trophic effect to gastrointestinal tract epithelium rather than as nutritive aim since the trophic effect accommodates the proliferation and maturation of the epithel and facilitated enzymes and hormone production to prepare digestion process. ${ }^{31-33}$ So does the maturation happened to the intestinal musculature, provided the good peristaltic coordina- tion and reduce reflux and regurgitation. The continuous and slow drip resulted in better tolerance, since it did not give tension to the gastric wall and reduce vagal risk that could result in apnea, as seen in bolus method. . $^{34-37}$

These facts prevent the prolonged withholding of enteral nutrition that is commonly practiced in LBW care. Embelton ${ }^{38}$ found similar results and did not find any necrotizing enterocolitis or other adverse effect in their study subjects. Innis et al ${ }^{30}$ also found that sepsis was frequent while feeding side effects were not found. This fact reflects that environment still influence the growth outcome.

This study found smaller weight gain compared to similar studies, may be this was caused by shorter period of observation. Schanler et al found weight gain as twice as this study in 60-day observation. While Vanderbilt et al did the study for 4 months and O'Connor et al for 12 months. ${ }^{29}$

Multiple regression analysis permits comparison of growth among subjects with variety of clinical circumstances. Growth determinants can be assessed after controlling other determinants, such as age, gender, gestational age, birth weight, length of birth, and head circumference at birth. This showed that all the growth indicators were only influenced by the type of milk, yet the length increment was also influenced by the length at birth, which means the calcium and phosphorus stores were better at the start.

The secondary results showed that FHM provided more calories. This result was similar to that of Embelton, which showed that calorie intake was superior compared to birth weight. Full feeding was also attained earlier in the FHM group. Full feeding means stable volume and calories throughout the day that provide calorie for catch up growth.

The less total volume to reach higher calories in the FHM group means the less tension to gastric wall. This is the benefit effect of FHM.

Since this study also used formula, then the results was not absolutely the effect of intervention.

Based on evidence based medicine, this study was valid, since we conducted randomization, although the importance was less by number needed to treat calculation.

In conclusion, FHM given to LBW infants with gestational age of less than 34 weeks for 30 days results in better weight gain, length increment, and head 
circumference increment compared to $\mathrm{HM}$ alone. While those with 1000-1499 g birth weight have better growth compared to those with 1500-1999 g birth weight. FHM provides more calories, thus earlier full feeding attainment, which results in better growth compared to HM alone. Priming and continuous gavages feeding practice lessen the adverse effects.

\section{Acknowledgements}

We would like to thank our consultants I Gde Raka Widiana and Ketut Tangking Widarsa; The Nursery staff of Neonatal Unit at Sanglah Hospital for their core support in the study. We also acknowledge John Fawcett and Rotary Club of Subiaco who provided the infuso feed pump and PT Wyeth Nutritional Indonesia which provided the SMA/S26 Human Milk Fortifier; and in particular; the infants taking part in the study and their families.

\section{References}

1. Rahmat ES. Masalah dan faktor risiko bayi BBLR di Puskesmas Karangasem, Pemalang. Medika 1996; 9:718-20

2. Setyowati T, Soesanto SS, Budioarso LR, Kristanti, Djaja S, Ma'roef S. Faktor-faktor yang mempengaruhi bayi lahir dengan berat badan rendah (Analisis lanjut SKDI, 1994). Bul Penelit Kesehat 1996;24:38-54

3. Hamid A, Hendra S, Lila N. Hubungan antara kadar prealbumin serum bayi berat lahir rendah dengan kadar prealbumin serum ibu di RSUP Denpasar. Majalah Kedokteran Udayana 1994;84:78-81

4. Soetjiningsih. Tumbuh kembang bayi berat lahir rendah. Presented at the Wyeth S-26/SMA HMF 1999 Symposium of tumbuh kembang BBLR \& human milk fortifier; 1999 Aug 7; Denpasar, Indonesia.

5. Barten J. Kematian perinatal di Rumah Sakit Gunung Maria Tomohon, Sulawesi Utara. Analisis 355 kasus. Medika 1992:19-24

6. Kornia K, Arsana W. Kematian perinatal di RSUP Denpasar 1990-1991. Majalah Kedokteran Udayana 1995;89:147-151

7. Monintja HE. Beberapa aspek kebutuhan bayi kurang bulan. In: Suradi R, Monintja HE, Amalia P, Kusumowardhani D, editors. Naskah lengkap pendidikan kedokteran berkelanjutan ilmu kesehatan anak XXXVIII. Jakarta: Balai Penerbit
FK UI; 1997

8. Greer FR, McCormick AM. Improved bone mineralization and growth in premature infants fed fortified own mother's milk. J Pediatr 1988;112:961-1

9. Schanler RJ, Garza C, Nichols BL. Fortified mother's milk for very low birth weight infants: results of growth and nutrient balance studies. J Pediatr 1985;103:437-45

10. Monintja HE. Masalah-masalah nutrisi enteral pada bayi kurang bulan. Proceedings of the Wyeth S-26/ SMA HMF 1999 Symposium.of tumbuh kembang BBLR \& human milk fortifier; 1999 Aug 7; Denpasar, Indonesia

11. Gultom E. Segi praktis nutrisi enteral bayi kurang bulan. Proceedings of the Wyeth S-26/SMA HMF 1999 Symposium.of tumbuh kembang BBLR \& human milk fortifier; 1999 Aug 7; Denpasar, Indonesia

12. Suradi R. Keuntungan pemberian ASI untuk bayi premature (kurang bulan). In: Suradi R, Monintja HE, Amalia P, Kusumowardhani D, editors. Naskah lengkap pendidikan kedokteran berkelanjutan ilmu kesehatan anak XXXVIII; 1997 April 7-8; Jakarta: Balai Penerbit FKUI; 1997

13. Hamid A. Prematuritas dan air susu ibu. In : Soetjiningsih, editor. ASI: petunjuk untuk tenaga kesehatan. Jakarta: EGC;1997. p. 59-60

14. Soetjiningsih. Peran air susu ibu dalam pencegahan dan penatalaksanaan diare akut. In: Soetjiningsih, editor. ASI: Petunjuk untuk tenaga kesehatan..Jakarta; EGC;1997. p.65-74

15. Soetjiningsih. Peran asam lemak esensial pada pertumbuhan otak anak. Presented in round table discussion PT Wyeth Indonesia; 2002 Apr 6; Denpasar, Indonesia.

16. Hay WW, Lucas A, Heird WC, Ziegler E, Levin E, Grave GD, et al. Workshop summary: nutrition of the extremely low birth weight infant. Pediatrics 1999;104:1360-8

17. Hall RT. Composition of Human Milk. Pediatr Clin of North America. Available from: URL: http:// www.mdconsult.com

18. Hall RT. Caroll RS. Infant feeding. Pediatr in Review 2000;21. Available from: URL: http:// www.mdconsult.com

19. Picciano MF. The evidence for breastfeeding. Nutrient composition of human milk. Pediatr Clin of North America 2001;48. Available from: URL: http:/ Lwww.mdconsult.com 
Dewi Kumara Wati Ketut et al: The efficacy of fortified human milk for the growth of LBW infants

20. Schanler RJ. The use of human milk for premature infants. Pediatr Clin of North America 2001;48. Available from: URL: http://www.mdconsult.com

21. Schanler RJ, Shulman RJ, Lau C. Feeding strategies for premature infants: beneficial outcomes of feeding fortified human milk versus preterm formula. Pediatrics 1999;103:1150-1156

22. McCain GC. A feeding protocol for healthy preterm infants that shortens time to oral feeding. J of Pediatr 2001; 139 Available from: URL: http:// www.mdConsult.com

23. Padmi IA. Manajemen laktasi. In: Soetjiningsih, editor. ASI: petunjuk untuk tenaga kesehatan. Jakarta: EGC;1997. p. 89-90

24. Stone DG, Forbes D, Hill R, Mikola D, Elgoni A, Boyd $\mathrm{D}$, et al. A New method for provision of enteral tube feeds. Proceedings of The XV International Conference of Nutrition;1993 Sept 20-Oct 1; Adelaide, Australia.

25. Berry MA, Abrahamowics M, Usher RH. Factors associated with growth in extremely low birth weight infants during initial hospitalization. Pediatrics 1997;100:640-6

26. Berry MA, Conrod H, Usher RH. Growth of very premature infants fed intravenous hyperalimentation and calcium supplemented formula. Pediatrics 1997;100:647-653

27. O'Connor DL, Hall R, Adamkins, Auestad N, Castillo $\mathrm{M}, \mathrm{E}$ Connor W, et al. Growth and development in preterm infants fed long chain polyunsaturated fatty acids: a prospective, randomized controlled trial. Pediatrics 2001;108:359-71

28. Innis SM, Adamkin DH, Hall RT, Kalhan SC, Lair C, Lim M, et al. Docosahexaenoic acid and arachidonic acid enhance growth with no adverse effects in preterm infants fed formula. J Pediatr 2002; 140. Available from: URL: http://www.mdconsult.com

29. S26/SMA Human Milk Fortifier. Manual Wyeth Nutritionals International.

30. Ernasari. S26/SMA human milk fortifier. Presented in Wyeth S26/SMA HMF 1999 Symposium. Tumbuh kembang BBLR \& human milk fortifier; 1999 Aug 7; Denpasar, Indonesia.

31. Thureen PJ. Early aggressive nutrition in neonate. Pediatrics in Review 1999;20:e45-55

32. Berseth CL. Minimal enteral feedings. Clinics in Perinatology 1995;22:195-205

33. Slagle TA, Gross SJ. Effect of early low volume enteral substrate on subsequent feeding tolerance in very low birth weight infants. J Pediatr 1988;113:526-31

34. Berseth CL. Neonatal small intestinal motility: motor responses to feeding in term and preterm infants. J Pediatr 1990;117:777-82

35. Lebenthal E. Gastrointestinal maturation and motility pattern as indicators for feeding the premature infant. Pediatrics 1995;95:207-9

36. Silvestre MAA, Morbach CA, Brans YW, Shankaran S. A prospective randomised trial; comparing continuous versus intermittent feeding methods in very low birth weight neonates. J Ped 1996;128:48-52

37. Berseth CL. Effect of early feeding on maturation of the preterm infant's small intestine. J Pediatr 1992;120:947-53

38. Embleton NE, Pang N, Cooke RJ. Postnatal malnutrition and growth retardation: an inevitable consequence of current recommendations in preterm infants? Pediatrics $2001 ; 107: 270-3$ 